
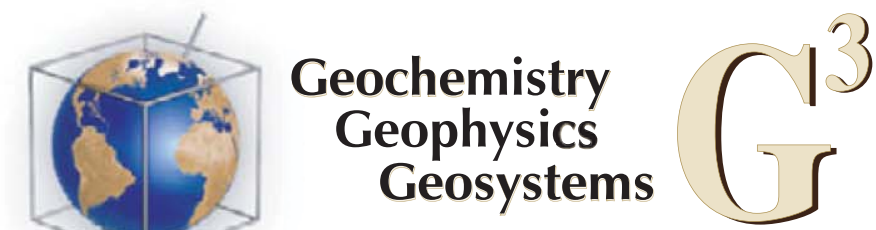

\title{
Sulfide geochronology along the Endeavour Segment of the Juan de Fuca Ridge
}

\author{
John W. Jamieson and Mark D. Hannington \\ Department of Earth Sciences, University of Ottawa, Ottawa, Ontario, Canada \\ David A. Clague \\ Monterey Bay Aquarium Research Institute, Moss Landing, California, USA \\ Deborah S. Kelley and John R. Delaney \\ School of Oceanography, University of Washington, Seattle, Washington, USA
}

James F. Holden

Department of Microbiology, University of Massachusetts, Amherst, Massachusetts, USA

\author{
Margaret K. Tivey \\ Woods Hole Oceanographic Institution, Woods Hole, Massachusetts, USA
}

\section{Linda E. Kimpe}

Department of Biology, University of Ottawa, Ottawa, Ontario, Canada

[1] Forty-nine hydrothermal sulfide-sulfate rock samples from the Endeavour Segment of the Juan de Fuca Ridge, northeastern Pacific Ocean, were dated by measuring the decay of ${ }^{226} \mathrm{Ra}$ (half-life of 1600 years) in hydrothermal barite to provide a history of hydrothermal venting at the site over the past 6000 years. This dating method is effective for samples ranging in age from $\sim 200$ to 20,000 years old and effectively bridges an age gap between shorter- and longer-lived U-series dating techniques for hydrothermal deposits. Results show that hydrothermal venting at the active High Rise, Sasquatch, and Main Endeavour fields began at least 850, 1450, and 2300 years ago, respectively. Barite ages of other inactive deposits on the axial valley floor are between $\sim 1200$ and $\sim 2200$ years old, indicating past widespread hydrothermal venting outside of the currently active vent fields. Samples from the halfgraben on the eastern slope of the axial valley range in age from $\sim 1700$ to $\sim 2925$ years, and a single sample from outside the axial valley, near the westernmost valley fault scarp is $\sim 5850 \pm 205$ years old. The spatial relationship between hydrothermal venting and normal faulting suggests a temporal relationship, with progressive younging of sulfide deposits from the edges of the axial valley toward the center of the rift. These relationships are consistent with the inward migration of normal faulting toward the center of the valley over time and a minimum age of onset of hydrothermal activity in this region of 5850 years.

Components: 5,903 words, 7 figures, 3 tables.

Keywords: hydrothermal; sulphide; geochronology; endeavour.

Index Terms: 1034 Geochemistry: Hydrothermal systems; 1032 Geochemistry: Mid-oceanic ridge processes; 1120 Geochronology: Isotopic disequilibrium dating.

Received 24 October 2012; Revised 22 March 2013; Accepted 26 March 2013; Published 8 July 2013. 
Jamieson J. W., M. D. Hannington, D. A. Clague, D. S. Kelley, J. R. Delaney, J. F. Holden, M. K. Tivey, and L. E. Kimpe (2013), Sulfide geochronology along the Endeavour Segment of the Juan de Fuca Ridge, Geochem. Geophys. Geosyst., 14, 2084-2099, doi:10.1002/ggge.20133.

\section{Introduction}

[2] The circulation of hydrothermal fluids through the oceanic crust at mid-ocean ridges (MORs) results in significant transfer of mass and energy between the oceans and underlying lithosphere. The rate and intensity of hydrothermal circulation has been investigated at scales ranging from the global ridge system [Baker and German, 2004; Davis and Elderfield, 2004; Hannington et al., 2011] down to the scale of individual discharging vents [Converse et al., 1984; Lowell et al., 1995; Von Damm, 1990]. Direct measurements of flow rate, fluid composition, and temperature provide only a snapshot of the physical and chemical attributes of a hydrothermal vent or vent field. Studies of vent fields along Juan de Fuca Ridge, an intermediate-spreading rate MOR in the northeastern Pacific Ocean, show that these attributes can vary significantly over timescales as short as days to weeks in response to tectonic and volcanic events [Butterfield et al., 1997; Embley et al., 1995; Hooft et al., 2010; Johnson et al., 2000; Kelley et al., 2012; Lilley et al., 2003; Seyfried et al., 2003]. In one instance, a chimney was observed to grow $1.2 \mathrm{~m}$ in a day after a microseismic event [Delaney et al., 1990], and the massive $45 \mathrm{~m}$ tall sulfide edifice known as "Godzilla", within the High Rise vent field, completely collapsed in 1996, with new growth of $10 \mathrm{~m} 1$ year later [Kelley et al., 2012]. Studies of the shortterm ( $<150$ years) growth rates of individual vent chimneys along Juan de Fuca Ridge, using shortlived uranium-series disequilibrium techniques such as ${ }^{210} \mathrm{~Pb} / \mathrm{Pb}$ and ${ }^{228} \mathrm{Th} /{ }^{228} \mathrm{Ra}$, indicate highly variable growth rates that range from 1 to $6 \mathrm{~cm} / \mathrm{yr}$ [Grasty et al., 1988; Kadko et al., 1985; Kim and McMurtry, 1991; Reyes et al., 1995; Stakes and Moore, 1991]. Because of this variability, meaningful rates of deposit growth over the lifespan of a hydrothermal system cannot be extrapolated from limited duration time-series observations or short-lived radioisotope studies.

[3] Longer-lived U-series isotope systems, such as ${ }^{230} \mathrm{Th} /{ }^{234} \mathrm{U}$, have been used to date active and inactive sulfide deposits along the East-Pacific Rise [Alt et al., 1987; Lalou et al., 1985], MidAtlantic [Kuznetsov et al., 2007; Lalou et al., 1995; Shilov et al., 2012], and Central Indian Ridge [Lalou et al., 1998]. Data from a detailed geochronological study of the TAG hydrothermal mound on the Mid-Atlantic ridge are consistent with venting occurring in long-lived pulses (up to 50,000 years), punctuated by periods of little to no sulfide deposition [Lalou et al., 1995]. This suggests that the lifespan of a hydrothermal system may be largely dependent on the local tectonic environment and may be inversely correlated with spreading rate. Hydrothermal systems associated with intermediate-rate spreading ridges (i.e., $4-6 \mathrm{~cm} / \mathrm{yr}$ ) are active over several thousands of years.

[4] Ages in the range of thousands of years cannot be determined using the short-lived isotope systems ( $<150$ years; e.g., ${ }^{210} \mathrm{~Pb} / \mathrm{Pb},{ }^{228} \mathrm{Th} /{ }^{228} \mathrm{Ra}$, $\left.{ }^{228} \mathrm{Ra} /{ }^{226} \mathrm{Ra}\right)$ or longer-lived systems $(>5000$; e.g., $\left.{ }^{230} \mathrm{Th} /{ }^{234} \mathrm{U}\right)$ that are most commonly used to date seafloor hydrothermal deposits. Radium-226, which has a half-life of 1600 years, can be used to determine the age of vent deposits between $\sim 200$ and 20,000 years old [de Ronde et al., 2005; Ditchburn et al., 2004], effectively bridging the age gap between shorter- and longer-lived isotopic systems.

[5] In this study, ages of a regionally extensive suite of sulfide-sulfate samples from hydrothermally active and inactive sites along the Endeavour Segment of the Juan de Fuca Ridge (Figure 1) were determined using the ${ }^{226} \mathrm{Ra} / \mathrm{Ba}$ method. The Endeavour Segment is spreading at a full rate of 6 cm/yr [Goldstein et al., 1991; Riddihough, 1984], and contains five known active vent fields, each spanning hundreds of meters in length, with a few small isolated areas of black smoker discharge, and several smaller areas of diffuse venting [Kelley et al., 2012]. There is also an abundance of inactive sulfide deposits, both within and between the active fields [Clague et al., 2008; Delaney et al., 1992; Glickson et al., 2006; Kelley et al., 2002, 2012]. Hydrothermal deposits at Endeavour are enriched 


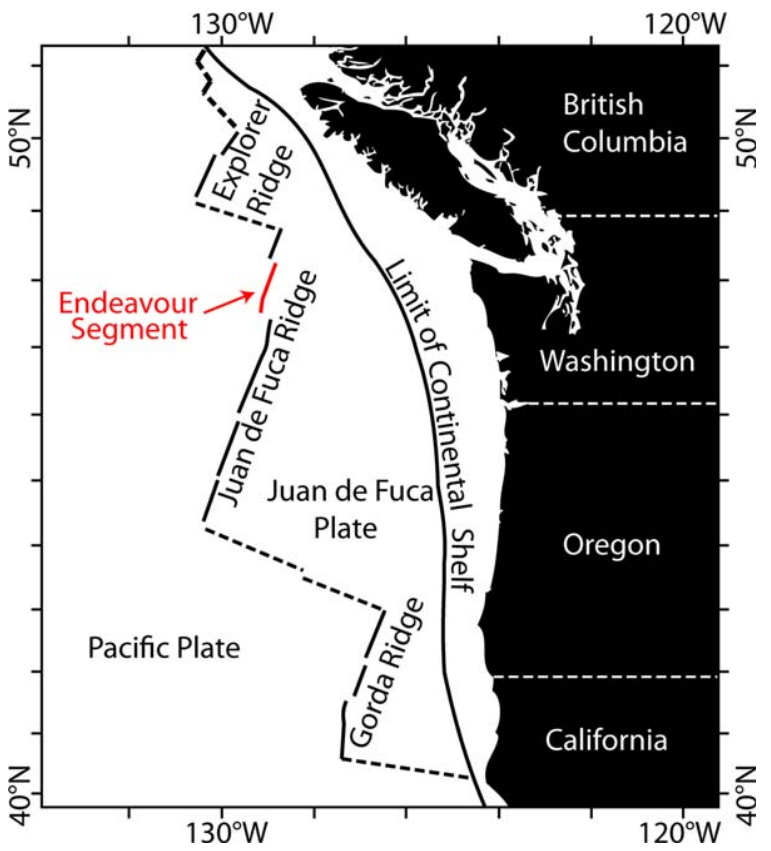

Figure 1. Map of the Juan de Fuca Plate showing the location of the Endeavour Segment.

in barite, relative to other MOR deposits [Kristall et al., 2006; Stakes and Moore, 1991; Tivey et al., 1999]. The barite is the primary host for the radiogenic isotope ${ }^{226} \mathrm{Ra}$, which is used to date these deposits. In this paper, we present age limits on hydrothermal activity and the spatial and temporal history of hydrothermal venting along the Endeavour Segment.

\subsection{Radium-226/Ba Dating of Hydrothermal Barite}

[6] Samples were dated by measuring the decay of ${ }^{226} \mathrm{Ra}$ within barite, largely following the methods of Ditchburn et al. [2004] and de Ronde et al. [2005]. Radium-226 accumulates in basaltic oceanic crust from the decay of ${ }^{238} \mathrm{U}$ and its intermediate daughter products. The immediate daughter isotope of ${ }^{226} \mathrm{Ra}$ decay (half-life of 1600 years) is ${ }^{222} \mathrm{Rn}$ (half-life of 3.8 days), with ${ }^{214} \mathrm{~Pb},{ }^{214} \mathrm{Bi}$, and ${ }^{210} \mathrm{~Pb}$ as other significant intermediate daughter isotopes further down the decay chain before ultimately decaying to stable ${ }^{206} \mathrm{~Pb}$. During hydrothermal alteration of the crust, both $\mathrm{Ra}$ and $\mathrm{Ba}$ are leached from basalt and transported to the seafloor by upwelling fluids. Radium has similar geochemical properties to $\mathrm{Ba}$ (e.g., ionic charge and radius) and substitutes readily for $\mathrm{Ba}$ within the barite lattice. Thorium-230, the immediate parent isotope of ${ }^{226} \mathrm{Ra}$, has very low solubility and is not leached from basalt during hydrothermal alteration, resulting in ${ }^{226} \mathrm{Ra}$ in hydrothermal barite being unsupported by its parent isotope. Sample ages ( $t$, in years) were calculated using the following formula:

$$
t=\frac{\operatorname{In}\left(N_{0} / N\right) \times 1600 \text { years }}{\operatorname{In} 2}
$$

where $N$ is the ${ }^{226} \mathrm{Ra} / \mathrm{Ba}$ of the sample at the time collected, $N_{0}$ is the initial ${ }^{226} \mathrm{Ra} / \mathrm{Ba}$ of the sample at the time of crystallization, and 1600 years is the half-life of ${ }^{226} \mathrm{Ra}$.

[7] The age of the sample is dependent on the amount of ${ }^{226} \mathrm{Ra}$ that has decayed, relative to the original ${ }^{226} \mathrm{Ra}$ content for each sample, which cannot be determined directly. However, the ${ }^{226} \mathrm{Ra} / \mathrm{Ba}$ of active, "zero-age" vents can be used as a proxy for initial ratios along the entire ridge [de Ronde et al., 2005], assuming that the ${ }^{226} \mathrm{Ra} / \mathrm{Ba}$ in the hydrothermal fluids does not vary spatially along the ridge segment or temporally over timescales of thousands of years. The lack of spatial variability of ${ }^{226} \mathrm{Ra} / \mathrm{Ba}$ can be tested by measuring the ratios in active deposits from various locations along the ridge segment. Temporal variability is much more difficult to ascertain directly. However, the ${ }^{226} \mathrm{Ra} /$ $\mathrm{Ba}$ of the source basalt for a ridge segment is unlikely to have changed significantly on a timescale of thousands of years [Butterfield et al., 1994; Von Damm, 1990].

\section{Geologic Setting}

[8] The Endeavour Segment forms a $90 \mathrm{~km}$ long section of the Juan de Fuca Ridge in the northeastern Pacific Ocean (Figure 1). The segment rises to a minimum depth of $2050 \mathrm{~m}$ below sea level (mbsl) along a central broad bathymetric high $\sim 15$ $\mathrm{km}$ in length (Figure 2). The depth of the segment gradually increases to the north and south, away from the central high, to a maximum depth of $>2700 \mathrm{~m}$ [Delaney et al., 1992]. A well-developed axial valley runs the center of the bathymetric high, varying in width between 500 and $1000 \mathrm{~m}$ [Delaney et al., 1992; Glickson et al., 2007; Kelley et al., 2002]. The valley walls are up to $200 \mathrm{~m}$ high and consist of a series of faulted half-grabens that form a step pattern rising from the valley floor, with steep walls that represent the topographic expressions of steep, inward-dipping normal faults [Delaney et al., 1992; Kappel and Ryan, 1986; Wilcock et al., 2009]. The $\sim 500 \mathrm{~m}$ wide valley floor consists of basaltic flows, 


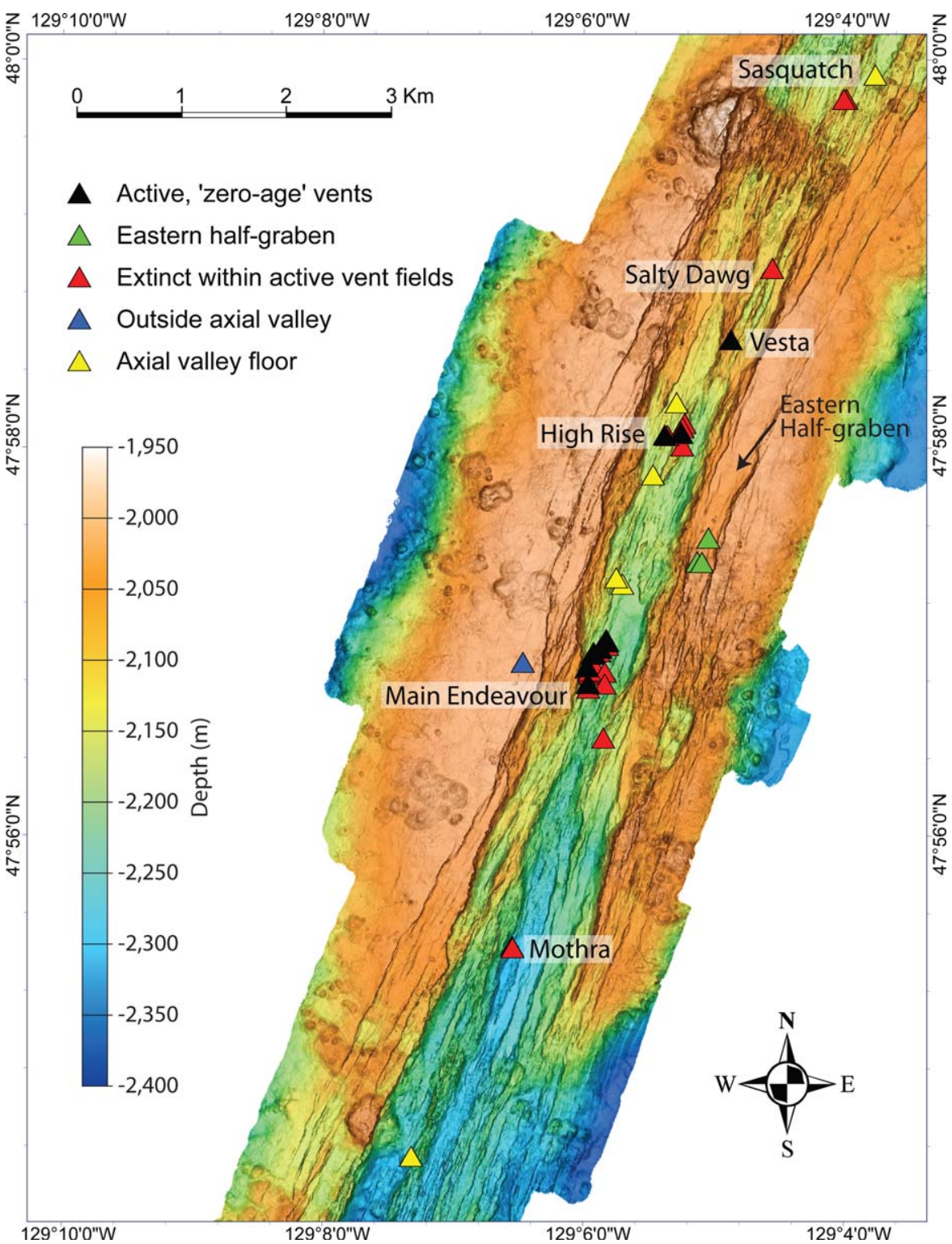

Figure 2. Detailed bathymetric map of the Endeavour Segment, with locations of the active vent fields and the hydrothermal sulfide samples dated in this study. The majority of samples were collected from active vent fields or inactive sites on the axial valley floor. Three samples were collected from a half-graben on the eastern valley wall, and a further sample was collected from outside the axial valley, on the western volcanic ridge. Bathymetry is $1 \mathrm{~m}$ resolution, collected between 2008 and 2011 , using the Monterey Bay Aquarium Research Institute (MBARI) autonomous underwater vehicle (AUV) D. Allan B.

collapsed lava lakes, and fissures. Given the absence of historic lava flows (i.e., $<30$ years old) within the axial valley, it has been suggested that the segment is currently volcanically inactive and is undergoing a period of fault-controlled extension, with the axial valley forming within the past 10,000 years based on spreading rate [Goldstein et al., 1991; Johnson et al., 2000; Proskurowski et al., 2004; Riddihough, 1984; Volpe and Goldstein, 1993]. However, recent seismic swarms in
1999, 2003-2004, and 2005 have been attributed to shallow diking events, resulting in changes in hydrothermal vent fluid temperatures, fluxes, and chemistry [Bohnenstiehl et al., 2004; Davis et al., 2001; Hooft et al., 2010; Lilley et al., 2003; Seyfried et al., 2003; Wilcock et al., 2009]. Recent seismic imaging shows a discontinuous series of strong reflectors at $1.9-4.0 \mathrm{~km}$ beneath the seafloor [Carbotte et al., 2012; Van Ark et al., 2007] that are interpreted to represent the top of a series of 
axial magma chambers that extend for $24 \mathrm{~km}$ along the Endeavour Segment [Van Ark et al., 2007] and indicate the potential for renewed volcanic activity.

[9] The Endeavour Segment hosts five discrete, areally extensive active hydrothermal vent fields with an average spacing of $2-3 \mathrm{~km}$ between fields (Figure 2). The fields host numerous large active and inactive sulfide edifices [Delaney et al., 1992; Glickson et al., 2006; Kelley et al., 2002, 2012; Robigou et al., 1993]. At Mothra and the Main Endeavour Field (MEF), hydrothermal activity occurs predominantly near the western edge of the axial valley, suggesting that the western bounding fault is a major conduit for ascending hydrothermal fluids [Delaney et al., 1992; Kelley et al., 2001; Tivey and Delaney, 1986]. Northward from these two fields, hydrothermal activity progressively moves toward the eastern valley walls (i.e., High Rise, Salty Dawg, and Sasquatch: see Figure 2). Lower-temperature, diffuse venting sites and abundant inactive hydrothermal chimneys and debris occur between the active vent fields [Clague et al., 2008; Kelley et al., 2002, 2012]. The active vent fields are characterized by steep-sided sulfide edifices that commonly rise several tens of meters above the seafloor and can each contain multiple active points of high-temperature discharge [Delaney et al., 1992; Glickson et al., 2007; Kelley et al., 2001; Kristall et al., 2006, 2011; Robigou et al., 1993; Tivey et al., 1999]. These structures are dominated by sulfide (principally pyrite, sphalerite, wurtzite, pyrrhotite, marcasite, and chalcopyrite) and sulfate (anhydrite and barite) minerals, with abundant amorphous silica [Delaney et al., 1992; Kristall et al., 2006; Robigou et al., 1993; Tivey and Delaney, 1986]. Barite is particularly abundant relative to typical MOR hydrothermal deposits [Hannington et al., 2005; Sours-Page et al., 1999]. This is interpreted to reflect deposition from vent fluids formed by interaction with basalt enriched in incompatible elements relative to normal MOR basalt [Karsten et al., 1990; Langmuir et al., 1997; Moore and Stakes, 1990].

\section{Samples}

[10] The majority of the $>300$ hydrothermal sulfide samples collected from the Endeavour Segment over the past 30 years were from active vents, biasing the current sample suite toward young deposits and the most recent hydrothermal activity. One notable exception was a study by
Tivey et al. [1999] that included samples from inactive sites between the MEF and High Rise fields. In our study, 36 sulfide samples were collected during several research cruises to the Endeavour segment between 2008 and 2011. The majority of the active and inactive samples from the active vent fields were collected during nine Alvin dives that were primarily focused on the collection of vent fluids and biological samples from the active vents. The visibly oldest and oxidized sulfides were targeted from partly eroded or collapsed chimney structures or talus from inactive areas within the vent fields. Samples collected outside of the active vent fields were collected on three dives with the ROV Doc Ricketts (with one sample collected with the ROV ROPOS). The dives with the Doc Ricketts focused on sampling basalts, sediment cores, and inactive sulfides from diverse locations both within the axial valley and on the ridge flanks, which allowed for the collection of sulfide samples from locations along the ridge segment not normally targeted for sulfide sampling. From the suite of 36 samples and the archive of more than 300 sulfide samples at the University of Washington, 61 samples were selected for analysis.

\section{Methods}

[11] Barium content for each sample was measured at ActLabs, in Ontario, either by fusion inductively coupled plasma mass spectrometry or by neutron activation. The reporting uncertainties for both methods are $<10 \%$ over the range of barium concentrations measured. The ${ }^{226} \mathrm{Ra}$ activity of each powdered sample was measured by XLBGWL-SV digital gamma spectrometry (DSPec, Ortec $($ ) containing a high-purity germanium crystal, $54.7 \mathrm{~mm} \times 66.2 \mathrm{~mm}$, and an active well depth of $40 \mathrm{~mm}$. The spectral signature was calibrated using IAEA-312 reference material. The single ${ }^{226} \mathrm{Ra}$ energy peak at $186 \mathrm{keV}$ is subject to interference from the decay of ${ }^{235} \mathrm{U}$ at the same energy level. Therefore, the activity of ${ }^{214} \mathrm{~Pb}$, a daughter isotope of ${ }^{226} \mathrm{Ra}$ via the intermediate isotope ${ }^{222} \mathrm{Rn}$ and a significant gamma emitter, was used as a proxy for ${ }^{226} \mathrm{Ra}$ activity. Lead-214 was chosen over ${ }^{214} \mathrm{Bi}$, another short-lived daughter product, due to the higher efficiency of the detector at the primary ${ }^{214} \mathrm{~Pb}$ energy peaks at 352 and $295 \mathrm{keV}$, relative to the primary ${ }^{214} \mathrm{Bi}$ peak at $609 \mathrm{keV}$, and because of effects of coincidence summing at the $609 \mathrm{keV}$ peak. Prior to counting, sample tubes were sealed for 21 days to prevent the escape of 
${ }^{222} \mathrm{Rn}$ gas and thereby attain secular equilibrium between ${ }^{226} \mathrm{Ra}$ and ${ }^{214} \mathrm{~Pb}$. Counting time for each sample varied between 2 and $23 \mathrm{~h}$, depending on the amount of ${ }^{226} \mathrm{Ra}$ in the sample. To ensure sufficient ${ }^{226} \mathrm{Ra}$ activity for gamma counting, samples with $\mathrm{Ba}$ concentrations of greater than $\sim 0.5 \mathrm{wt} \%$ were chosen for analysis. These samples required shorter counting times and gave higher precision results [de Ronde et al., 2005; Ditchburn et al., 2004]. The resulting gamma spectra were analyzed using a software program developed and provided by Dr. Peter Appleby (University of Liverpool, U.K.), which corrects for background, detector efficiency, sample volume, and matrix effects.

[12] Of the 61 samples analyzed, 12 were collected from active or recently active chimneys and are considered to be zero-age samples (Table 1) and were used to determine the initial ${ }^{226} \mathrm{Ra} / \mathrm{Ba}$ value $\left(N_{0}\right)$, which is defined by the slope of a regression curve through these samples on a ${ }^{226}$ Ra-activity versus $\mathrm{Ba}$ concentration plot (Figure $3 \mathrm{a}$ ). From this plot, an $N_{0}$-value of $1275 \pm 70(1 \sigma) \mathrm{Bq} / \mathrm{kg} \cdot \mathrm{wt}$ $\% \mathrm{Ba}$ was used as the initial value for all Endeavour samples. The 12 samples used to define this value were collected from sites of active venting on hydrothermal edifices within MEF (9) and High Rise (2) fields and an actively venting edifice (named Marias) discovered in 2011 within the newly identified Vesta vent field, located between High Rise and Salty Dawg (Figure 2) [Kelley et al., 2012]. The two samples from the High Rise field in Figure 3a (ALV2461-R13TIP and ALV2463-R5c3) were documented as "inactive" when collected, but have ${ }^{226} \mathrm{Ra} / \mathrm{Ba}$ ratios that are consistent with the ratios of active samples from MEF and so are included. The ${ }^{226} \mathrm{Ra} / \mathrm{Ba}$ values of these samples are also the highest ratios recorded at High Rise, indicating that these samples are young, relative to the other samples from there. The ${ }^{226} \mathrm{Ra} / \mathrm{Ba}$ value of the sample from Marias is slightly higher than the maximum values from MEF and High Rise, likely a result of minor variability in ${ }^{226} \mathrm{Ra} / \mathrm{Ba}$ values along the ridge segment. The $R^{2}$-value for the regression line is 0.971 , indicating a good agreement in maximum, zero age ${ }^{226} \mathrm{Ra}$ / $\mathrm{Ba}$ values at MEF, High Rise, and Marias. This ratio is used to calculate ages for inactive samples along the entire ridge segment.

[13] Age uncertainties were calculated by standard error propagation through the decay equation of the uncertainties of the $\mathrm{Ba}$ content and ${ }^{226} \mathrm{Ra}$ activities for both the analyzed sample and the value used for the initial ratio inputs into the decay equation.

\section{Results}

\section{1. ${ }^{226} \mathrm{Ra} / \mathrm{Ba}$ Ratios of Inactive Samples}

[14] None of the ${ }^{226} \mathrm{Ra} / \mathrm{Ba}$ values from 49 samples classified as "inactive" plot above the regression line that is defined by the active samples (Figure $3 \mathrm{~b}$, Table 2). This relationship is a necessary condition if the ${ }^{226} \mathrm{Ra} / \mathrm{Ba}$ defined by the zero-age samples is representative of the initial ratio for all ancient samples. Age uncertainties range from 125 to 210 years with an average of 135 years. Because of these uncertainties, the ${ }^{226} \mathrm{Ra} / \mathrm{Ba}$ method is considered unsuitable for the two samples from Mothra and the youngest inactive sample from MEF $(25 \pm 125$ years, $15 \pm 125$ years, and $200 \pm 125$ years, respectively).

[15] Inactive samples range in age from recent to $\sim 6000$ years, with all but one sample having ages of less than 3000 years (Figure 4). The single sample older than 3000 years is also the only sample

Table 1. ${ }^{226} \mathrm{Ra}$ Activities and Ba Content for Zero-Age Hydrothermal Sulfide Samples

\begin{tabular}{|c|c|c|c|c|c|c|c|}
\hline Sample Number & Vent Field & Structure & Lattitude & Longitude & $\mathrm{Ba}($ wt \%) & $\begin{array}{c}{ }^{226} \mathrm{Ra} \text { Activity } \\
(\mathrm{Bq} / \mathrm{kg})\end{array}$ & $\begin{array}{c}{ }^{226} \mathrm{Ra} / \mathrm{Ba} \\
(\mathrm{Bq} / \mathrm{kg} \cdot \mathrm{wt} \%)\end{array}$ \\
\hline ALV2449-1 & MEF & Grotto & 47.94911 & -129.09868 & 1.6 & $1908 \pm 7$ & 1193 \\
\hline ALV4448-2211 & MEF & $\mathrm{TP}$ & 47.94898 & -129.09885 & 0.9 & $1313 \pm 5$ & 1521 \\
\hline ALV4517-1718 & MEF & Crypto & 47.95008 & -129.09696 & 0.7 & $1006 \pm 5$ & 1433 \\
\hline ALV4446-1735 & MEF & Salut & 47.94646 & -129.09939 & 1.2 & $1760 \pm 6$ & 1479 \\
\hline ALV4452-1706 & MEF & Hulk & 47.95022 & -129.09712 & 0.4 & $454 \pm 3$ & 1203 \\
\hline ALV4438-1816 & MEF & Bastille & 47.94789 & -129.09954 & 0.3 & $415 \pm 3$ & 1348 \\
\hline ALV4525-0134 & MEF & Dante & 47.94948 & -129.09778 & 0.7 & $972 \pm 5$ & 1363 \\
\hline ALV4449-1630 & MEF & Hulk & 47.95005 & -129.09689 & 2.1 & $2671 \pm 8$ & 1254 \\
\hline ALV4517-1703 & MEF & E. of Hulk & 47.95012 & -129.09696 & 0.5 & $725 \pm 4$ & 1549 \\
\hline ALV2461-R13 TIP & High Rise & Baltic & 47.96796 & -129.08747 & 4.6 & $6135 \pm 15$ & 1334 \\
\hline ALV2463-R5c3 & High Rise & E. of Ventnor & 47.96882 & -129.08707 & 1.8 & $2412 \pm 9$ & 1340 \\
\hline D264-R3 & S. of Salty Dawg & Marias & 47.97601 & -129.08115 & 0.7 & $1755 \pm 113$ & 2635 \\
\hline
\end{tabular}

Samples starting with "ALV" or "D" were collected using the ALVIN submersible or ROV Doc Ricketts, respectively. The three or four digits that immediately follow refer to the dive number for when the sample was collected. The number after the dash is either the sample number for that dive or the time at which the sample was collected (four digits). 

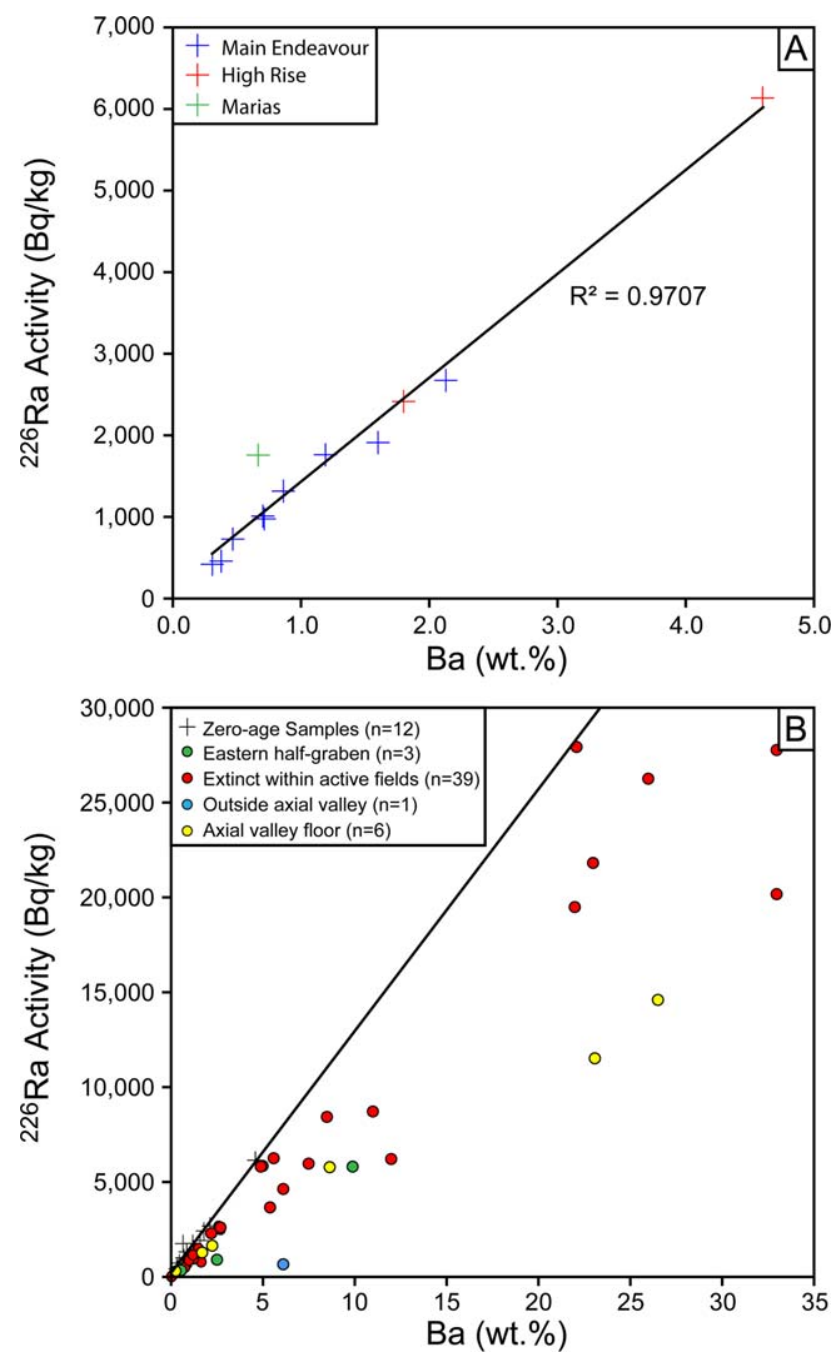

Figure 3. (a) ${ }^{226}$ Ra activity versus Ba content for zero-age samples from the Endeavour Segment. The majority of the zero-age samples are from the Main Endeavour and High Rise Fields. One active sample was collected from "Marias", a newly discovered active vent south of the Salty Dawg Field. The slope of the linear regression line is assumed to be the initial ${ }^{226} \mathrm{Ra} / \mathrm{Ba}$ value $\left(N_{0}\right)$ for all inactive sulfides along this segment. The uncertainty for $N_{0}$ is calculated from the standard deviation of the slope of the regression line. (b) ${ }^{226} \mathrm{Ra}$ activity versus $\mathrm{Ba}$ content for inactive samples from the Endeavour Segment. Solid line represents

collected from outside the axial valley, west of the westernmost axial valley fault scarp on the volcanic ridge (Figure 2), and has an age of $5850 \pm 205$, which is twice as old as the next oldest sample. All samples younger than 1300 years $(n=34)$ are from the active vent fields. Samples older than 1300 years $(n=15)$ are from deposits both within and outside of the active fields (Figure 4).

[16] Of the nine samples from inactive sulfide structures outside of the major vent fields, but within the axial valley, six were collected from the axial valley floor and three from the eastern halfgraben on the slope of the valley. The samples on the axial valley floor range from 1230 to
$2170 \pm 125$ years old (Figure 4 ). These ages are generally older than those from the active fields, although there is some overlap in ages. Three samples from the eastern half-graben range in age from 1705 to $2925 \pm 210$ years old and are much older than most samples from the axial valley floor.

[17] Twenty-one samples from MEF show a wide age spectrum from recent to 2270 years, with 16 of the samples having ages between 500 and 1500 years (Figure 4). The 13 samples from the High Rise Field have a younger age range than the samples from MEF, with ages from present to a maximum age of 845 years (Figure 4 ). Five of the 
Table 2. ${ }^{226} \mathrm{Ra} / \mathrm{Ba}$ Ages for Inactive Hydrothermal Sulfides Samples

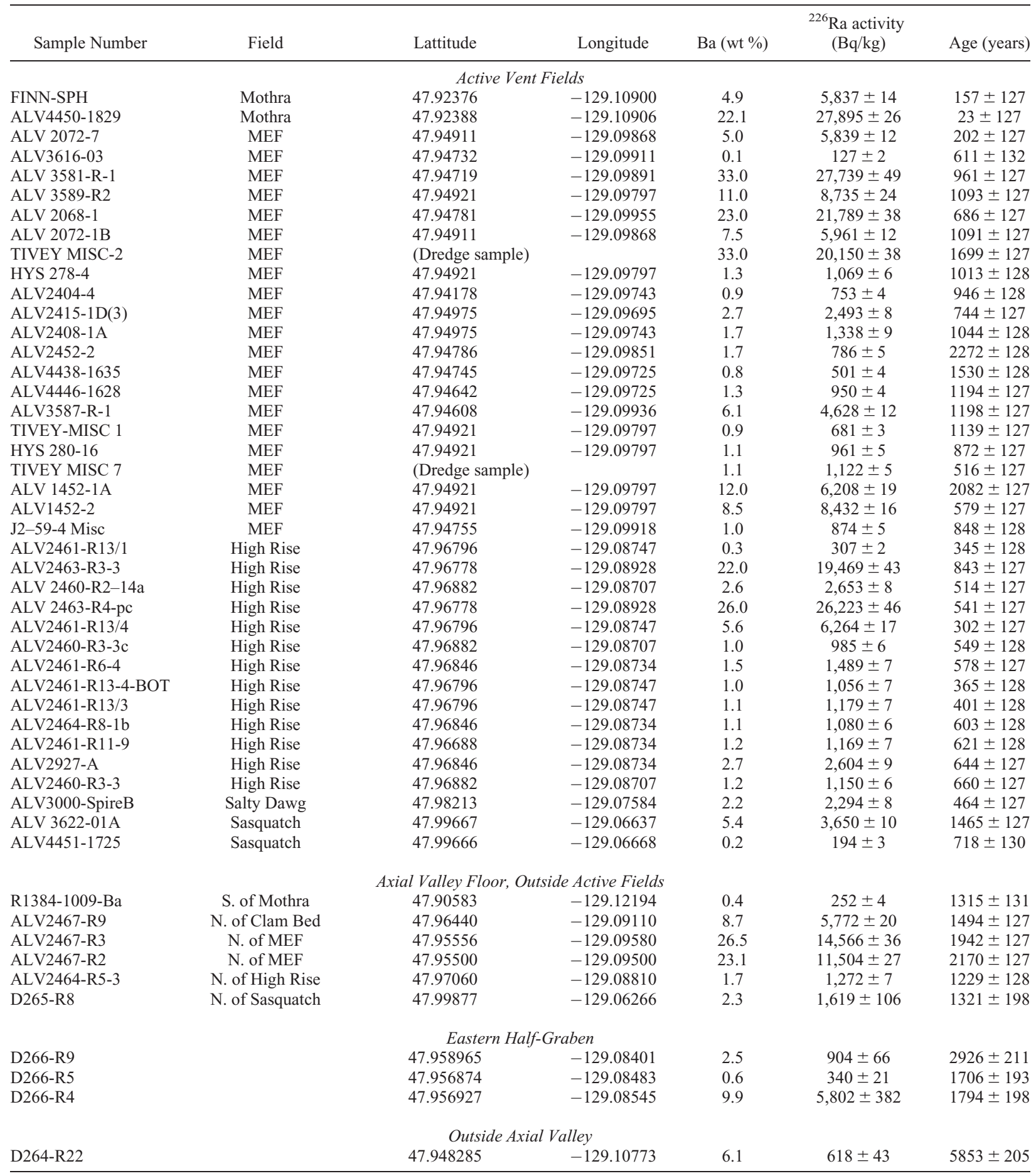

Samples starting with "ALV" or "D" were collected using the ALVIN submersible or ROV Doc Ricketts, respectively. The three or four digits that immediately follow refer to the dive number for when the sample was collected. The number after the dash is either the sample number for that dive or the time at which the sample was collected (four digits).

samples collected at High Rise are subsamples of an active spire on the "Baltic" edifice at High Rise (ALV2461-R13). Four of the five subsamples from this spire returned ages from 300 to 400 years and are all within analytical uncertainty of each other (Table 2). These subsamples can be grouped and considered a single sample with an average age of 355 years. The fifth subsample (R13TIP) was taken from the top of the spire and is considered a zero-age sample (Table 1). The 


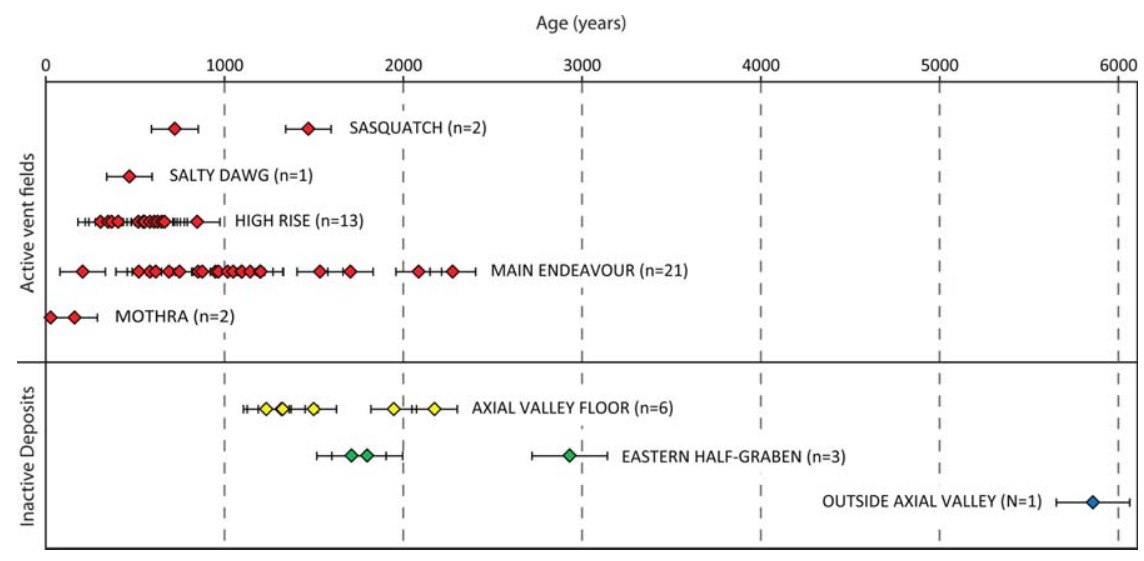

Figure 4. Age distribution of hydrothermal sulfide samples from the Endeavour Segment, subdivided by vent field (top) and location on the ridge outside of the active vent fields (bottom). Forty-eight of 49 samples are younger than 3000 years. The oldest sample, at $\sim 6000$ years old, is twice as old as the next oldest sample, and is from outside the axial valley. Samples younger than $\sim 1300$ years are all from the active vent fields. For both MEF and High Rise Fields, sulfide accumulation has been relatively continuous since the earliest recorded evidence of venting at each respective site, suggesting a stable hydrothermal heat source and fluid circulation system over the lifespan of these vent fields.

23 year old sample (ALV4450-2829) was collected from a dead, toppled but still relatively intact, chimney at the base of the active Faulty Towers Complex. Only one dateable sample was collected from the Salty Dawg field, with an age of 465 years. Two samples from the Sasquatch field yielded ages of 720 and 1465 years old (Figure 4).

\section{Discussion}

\subsection{Venting History Within the Endeavour Axial Valley}

[18] The 49 nonzero age determinations of hydrothermal sulfide samples from the Endeavour segment provide the first quantitative characterization of the spatial and temporal history of venting along the segment. The active vent fields represent discrete hydrothermal systems controlled by faulting along the axis of the valley [Delaney et al., 1992; Kelley et al., 2012; Robigou et al., 1993]. Data from MEF and High Rise provide the most information on the chronology of venting within the currently active fields with 21 and 13 dates, respectively.

[19] The spectrum of ages from the MEF (Figure 4) suggests that it has been hydrothermally active for at least $\sim 2300$ years. More samples would be required to determine whether venting was truly continuous, as hiatuses of less than 500 years cannot be resolved with these data. Direct observations of vent activity at MEF since 1984 show that the intensity of venting had been relatively stable from the mid-1980s until 1999-2000, when major shifts in temperature, fluid chemistry, and fluid flux occurred, and nascent chimneys formed in response to the emplacement of dikes [Butterfield et al., 1994; Kelley et al., 2012; Larson et al., 2009; Lilley et al., 2003; Seyfried et al., 2003; Wilcock et al., 2009]. Although a sampling bias cannot be ruled out, the large number of samples with ages between $\sim 500$ and 1250 years (Figure 4) may indicate a high rate of sulfide deposition during this time period, perhaps as a result of multiple faulting or similar dike emplacement events.

[20] The High Rise field has been active for at least $\sim 840$ years (Figure 4). Similar to MEF, the sample age distribution shows no prolonged venting hiatuses (i.e., $>500$ years) during this time period (Figure 4). The two dated samples from the Mothra Field were collected from the actively venting Faulty Towers Complex. Their young ages are unlikely to reflect the age of the entire complex, which consists of numerous vents and inactive structures that have yet to be sampled.

[21] Although hydrothermal activity is currently focused at the five major active vent fields with minor venting associated with smaller vent fields and diffuse discharge areas [Kelley et al., 2012], the abundance of sulfide debris on the axial valley floor outside of these areas (Figure 2) indicates that past hydrothermal venting along the Endeavour Segment has not been restricted to these 
currently active areas. Of the few sulfide samples collected from outside the active vent fields, all are older than $\sim 1200$ years, indicating that locations of hydrothermal venting and sulfide deposition along the axial valley 1200 years ago differ from what is observed today (Figure 4). However, sample ages older than 1200 years from both MEF and Sasquatch show that these two fields were active in their current locations at that time. The absence of periods of $>500$ years without sulfide deposition, over the last $\sim 2300$ years at MEF and $\sim 850$ years at High Rise, indicates relatively stable, long-lived hydrothermal systems beneath these locations (Figure 4).

[22] Hydrothermal venting is commonly focused within the axial valley of intermediate-rate MORs, due to local shallow heat sources and enhanced permeability from normal faulting [Hannington et al., 2005]. With spreading, sulfide deposits become progressively older away from the ridge axis, although this relationship may be complicated by local effects such as faulting, shallow diking events, and heterogeneous permeability [Kappel and Ryan, 1986; Lalou et al., 1985; Petersen et al., 2009].

[23] Results from this study support the general observation that the age of inactive vent sites becomes progressively older away from the ridge axis (Figure 4), with active hydrothermal venting largely restricted to the present valley floor, and only minor, diffuse venting occurring on the valley walls and half-grabens. The axial valley-bounding normal faults can be traced over several kilometers of ridge length and are spatially associated with older sulfide deposits [Delaney et al., 1992; Kadko and Butterfield, 1998]. Although dated sulfides on the valley floor are mostly younger than 2000 years, the youngest sample from the eastern half graben is $1705 \pm 195$ years old (Figure 4 ). The oldest dated mineralization $(5850 \pm 205$ years $)$ is furthest from the ridge axis, situated outside the current axial valley on the western volcanic ridge, and $\sim 200 \mathrm{~m}$ west of the outermost valley fault scarp.

[24] Because of the link between seismicity, faulting, and hydrothermal discharge at Endeavour [Carbotte et al., 2006; Wilcock et al., 2009], the dating of the sulfide deposits sheds new light on the history of axial valley evolution. The pattern of progressively older hydrothermal venting, from the central valley floor to outside the axial valley, is consistent with the youngest faults active at the axis and older faults being rafted off-axis by spreading (Figure 4), similar to slow-spreading ridges [Macdonald, 1982; Solomon et al., 1988]. In the southern half (Mothra to MEF) of the Endeavour Segment, active venting occurs along the innermost western fault scarp, which acts as the primary conduit for hydrothermal upflow [Delaney et al., 1992; Glickson et al., 2007; Kelley et al., 2001]. Heat-flow measurements by Johnson et al. [2010] for the MEF area are consistent, with upflow occurring along the western edge of the axial valley and recharge occurring at the eastern valley wall and half-grabens.

[25] On fast-spreading ridges, deposits outside the axial valley are generally inactive because they are spread rapidly away from the shallow, focused axial heat source. At the slower spreading Endeavour segment, where current-focused hydrothermal venting appears to be restricted to the axial valley floor, ridge flank sulfide deposits outside of the valley may have formed before the formation of the current axial valley. If the hydrothermal deposit on the western ridge flank (D264-R22) formed prior to the current axial valley, the age of the recovered sample constrains the maximum age of the current valley to $\sim 5850$ years.

[26] The deposition of sulfide material on the eastern half-graben at 2925 years suggests that, at this time, the graben may have formed part of the axial valley floor. Sulfide ages from the eastern half-graben and the valley floor indicate that venting occurred both on the half-graben and the valley floor between $\sim 2270$ and 1710 years ago. The absence of sulfide material younger than 1700 years ago on the eastern half graben suggests that faulting and further subsidence after this time shifted hydrothermal venting solely to the current valley floor. The sulfide ages suggest that hydrothermal venting was more widespread over the valley floor until $\sim 1230$ years ago, when venting became limited to the current fields.

[27] Sulfide ages define the minimum ages for the substrate on which they are deposited. Portions of the current axial valley floor at Endeavour are thus older than $\sim 2300$ years. The single sample from the top of the western volcanic ridge constrains the lava flow in that immediate area to $>5850$ years. However, limited spatial resolution of sulfide ages along the ridge segment prevents a reconstruction of the eruptive history at Endeavour, as the dated sulfides are more widely spaced than individual lava flows.

[28] The axial valley floor is composed of a combination of collapsed preexisting crust forming a 
graben system and more recent basalt flows within the axial valley that are constrained by the valley walls [Carbotte et al., 2006]. Although no volcanic activity has been recognized at Endeavour over the past 30 years, evidence of diking events along the Endeavour Segment is well documented [Bohnenstiehl et al., 2004; Carbotte et al., 2012; Davis et al., 2001; Hooft et al., 2010; Kelley et al., 2012]. The nonvertical fault scarps that form the axial valley walls indicate that extension along the ridge segment in the recent past has likely been accommodated by both diking and normal faulting, and thus the age of the valley cannot be simply related to the valley width and spreading rate. Most faults are roughly parallel to the axis of the axial valley, continuous over several $\mathrm{km}$, and have exposed scarps that dip toward the center of the valley (with the exception of a few minor antithetic faults) (Figure 5). The cumulative horizontal displacement of the normal faults at the seafloor (Table 3), combined with the age of the axial valley, can be used to determine the rate of faultaccommodated spreading along the segment. The faults are divided into east-dipping and west-dipping faults on the western and eastern flanks of the valley, respectively. Fault throws were measured along the three cross sections that strike perpendicular to the ridge axis (Figure 5). Faults that bound the central horst hosting the High Rise field in section $\mathrm{A}-\mathrm{A}^{\prime}$ are included, although their spatial
Table 3. Cumulative Horizontal Offsets of Normal Faults within Axial Valley

\begin{tabular}{|c|c|c|c|c|c|c|c|}
\hline \multirow[b]{2}{*}{ Cross-Section } & \multicolumn{2}{|c|}{$\begin{array}{l}\text { Pacific } \\
\text { Plate }\end{array}$} & \multicolumn{2}{|c|}{$\begin{array}{c}\text { Juan de } \\
\text { Fuca } \\
\text { Plate }\end{array}$} & \multicolumn{2}{|c|}{$\begin{array}{c}\text { Central } \\
\text { Horst }\end{array}$} & \multirow[b]{2}{*}{ Total (m) } \\
\hline & $n$ & (m) & $n$ & (m) & $n$ & (m) & \\
\hline$A-A^{\prime}$ & 3 & 216 & 4 & 186 & 2 & 98 & 427 \\
\hline B-B' & 4 & 227 & 4 & 209 & & & 435 \\
\hline $\mathrm{C}-\mathrm{C}^{\prime}$ & 6 & 143 & 7 & 210 & & & 426 \\
\hline Average & 4 & 195 & 5 & 202 & 2 & 98 & 429 \\
\hline
\end{tabular}

relationship to the locus of spreading is uncertain (Figure 5).

[29] The results show that the cumulative horizontal throw on either side of the valley is essentially symmetrical, with the average total measured extension across the western valley wall within $3 \%$ of extension along the eastern wall (Table 3 ). Between sections $\mathrm{A}-\mathrm{A}^{\prime}$ and $\mathrm{C}-\mathrm{C}^{\prime}$, the total horizontal extension across the valley is also relatively constant along its length, ranging from 426 to $435 \mathrm{~m}$ for the three cross sections, averaging $429 \mathrm{~m}$.

[30] Using the maximum valley age of $5850 \pm 205$ years, as defined by the age of the single sulfide from the top of the western volcanic ridge, extension accommodated by normal faults (i.e., not including extension due to dike emplacement and volcanic eruptions) has been occurring at an
A.

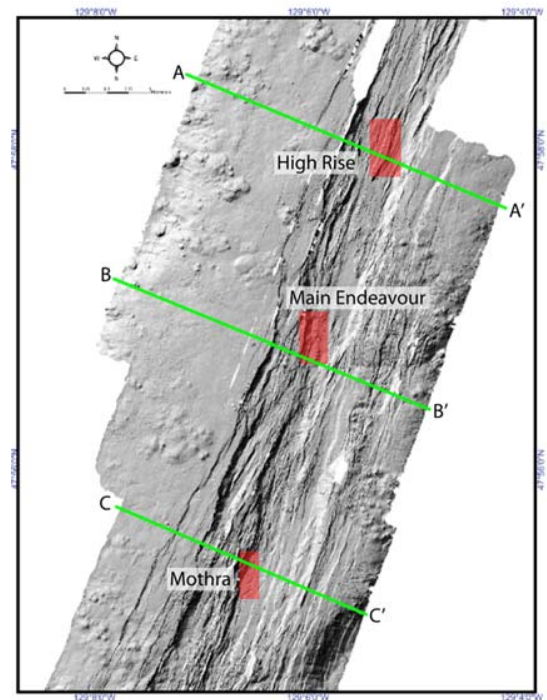

B.
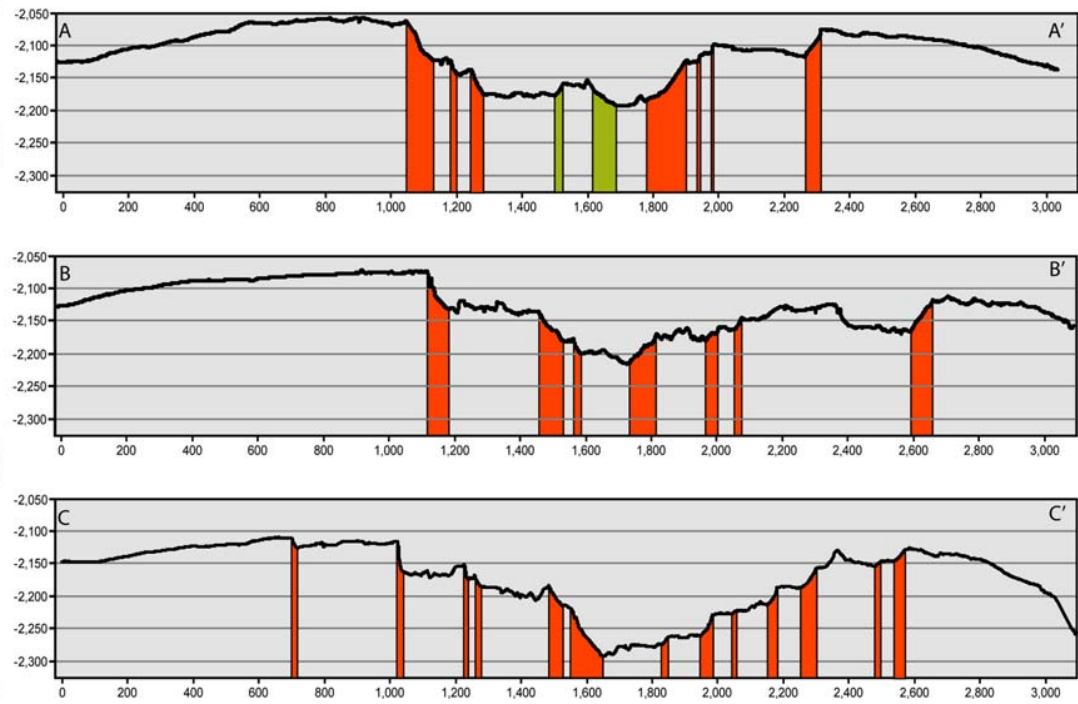

Figure 5. (a) Hill-shaded map of the central Endeavour Segment showing locations of cross-sections. (b) Shaded areas show total horizontal offset for each fault on the valley walls (orange) and the central horst in section A-A' (green). Vertical exaggeration of the cross-sections is $2 x$. Total offsets summarized in Table 3. 
averaged full rate of at least $7.3 \mathrm{~cm} / \mathrm{yr}$. The currently accepted full spreading rate of $\sim 6 \mathrm{~cm} / \mathrm{yr}$ for the Juan de Fuca Ridge, defined using magnetic anomaly analysis [Riddihough, 1984] and U-Th ages of basalts [Goldstein et al., 1991], is an average over the length of the entire ridge and integrates tens of thousands to several million years of extension. The spreading rate can, however, vary over shorter timescales and along different segments of the ridge [Riddihough, 1984]. Based on movement vectors calculated for either side of the axial valley of the Endeavour Segment (relative to the North American Plate) using the Global Positioning System velocity-generated Global Strain Rate Map (GSRM 1.2) [Kreemer et al., 2003], this segment is currently spreading at a rate of $4.9 \pm 0.2$ $\mathrm{cm} / \mathrm{yr}$. The fast rate calculated using fault-related extension and the suggested age of the axial valley may be an indication that the current axial valley is in fact older than the oldest dated sulfide $(\sim 5850$ years old).

\subsection{Ages of Sulfides at Other MOR}

[31] A compilation of seafloor sulfide ages from MORs $(n=300)$ shows deposit ages that range from $<10$ to $>100,000$ years (Figure 6). With the exception of data from this study, the majority of ages were determined using shorter-lived U-series isotope systems such as ${ }^{210} \mathrm{~Pb} / \mathrm{Pb}$ ( $<150$ years) or longer-lived systems such as ${ }^{230} \mathrm{Th} /{ }^{234} \mathrm{U}(>\sim 2000$ years). Previously, this resulted in a significant gap in recorded sulfide ages between $\sim 200$ and 2000 years, highlighted by the black hatched

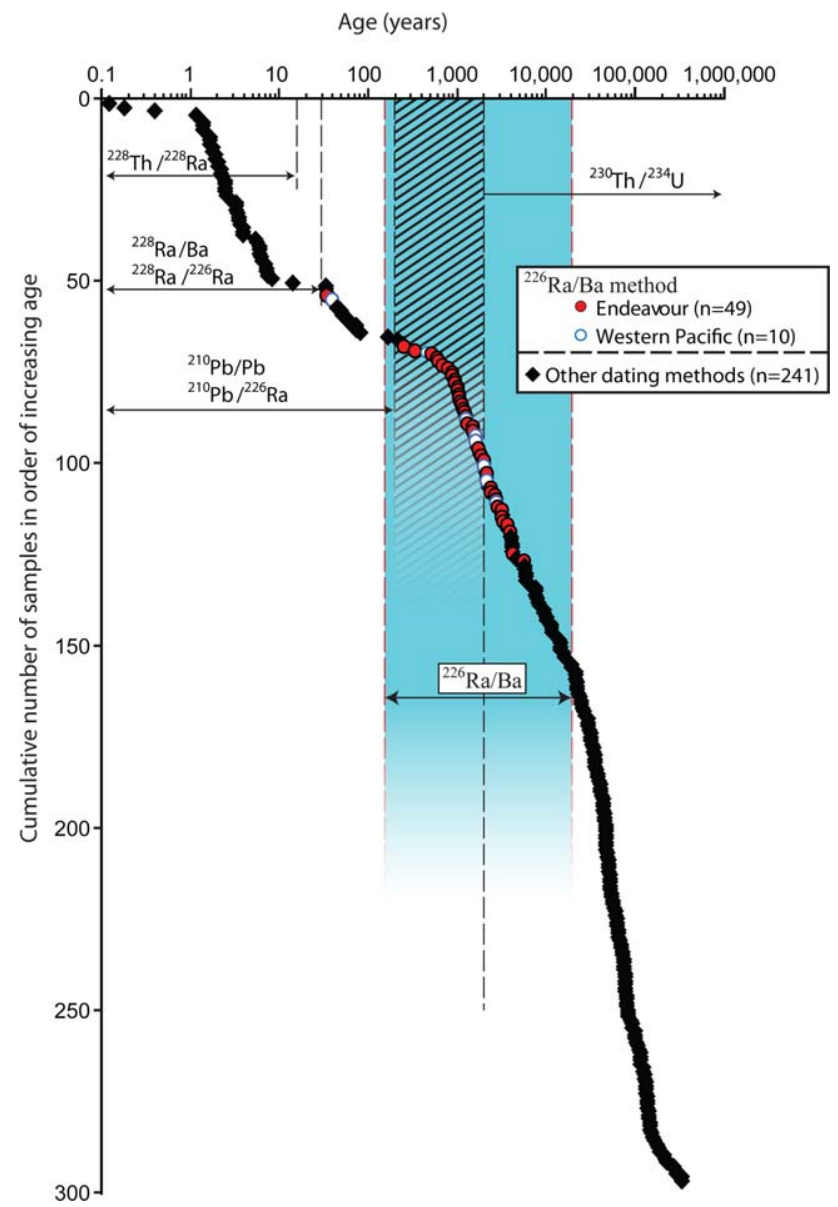

Figure 6. Age distribution of 300 sulfides from 18 seafloor hydrothermal deposits around the world. The oldest sulfide dated so far is only 176,200 years old, from the Petersburg site, Mid-Atlantic Ridge [Shilov et al., 2012]. The effective age ranges for different U-series isotope systems are indicated, with the ${ }^{226} \mathrm{Ra} / \mathrm{Ba}$ system highlighted in blue. Samples from Endeavour (this study), Brothers [de Ronde et al., 2005; Ditchburn et al., 2012], and single samples from Clark and East Diamente volcanoes [Ditchburn et al., 2012] are the only samples dated using the ${ }^{226} \mathrm{Ra} / \mathrm{Ba}$ system. The black-hatched pattern shows the age gap between other U-series systems that is effective bridged by the ${ }^{226} \mathrm{Ra} / \mathrm{Ba}$ system. Data for other methods from Cherkashov et al. [2010], de 
pattern in Figure 6 . The ${ }^{226} \mathrm{Ra} / \mathrm{Ba}$ dating technique, with an effective range of $\sim 200-20,000$ years (highlighted in blue in Figure 6) fills this important gap. Besides this study, the only other sulfides with ages that fall within this time gap are from the Brothers volcano, on the southern Kermadec arc [de Ronde et al., 2005; Ditchburn et al., 2012] and single samples from the Clark and East Diamente volcanoes [Ditchburn et al., 2012]. The majority of older ages $(>\sim 10,000$ years) are from deposits on the intermediate-rate Central Indian Ridge, the slow-spreading Mid-Atlantic Ridge, and the ultraslow Southwest Indian Ridge [Cherkashov et al., 2010; Kuznetsov et al., 2011; Lalou et al., 1998; Munch et al., 2001; Shilov et al., 2012]. The oldest documented seafloor sulfide sample was dated at 176,200 $\pm 59,000$ years from the Petersburg site $\left(19^{\circ} 52 \mathrm{~N}\right)$ on the Mid-Atlantic Ridge [Shilov et al., 2012]. In most cases, only the most recent deposits near the spreading axes have been dated; deposits that are more than $5 \mathrm{~km}$ off-axis would have formed on crust that is at least $\sim 250,000$ years old. The paucity of information on older deposits is a reflection of the difficulty in locating inactive, offaxis deposits and the focus by most workers on active systems. The fate of these inactive sulfide deposits over time remains unclear, with preservation on the seafloor affected by sulfide oxidation, burial by sediment or lava, and microbial activity.

[32] Compared to the ages of sulfides from intermediate-, slow-, and ultraslow-spreading ridges, the maximum age from the axial summit trough of the fast-spreading East-Pacific Rise $\left(13^{\circ} \mathrm{N}\right)$ is only
170 years [Lalou et al., 1985]. The negative correlation between deposit age and spreading rate (Figure 7) is likely a reflection of the amount of time a section of oceanic crust resides within the hydrothermally active neovolcanic zone of a spreading center, the propensity for lava flows to cover the hydrothermal sites more regularly, and the reorganization of hydrothermal upflow zones associated with diking eruptive events. Because the age range provided by the ${ }^{226} \mathrm{Ra} / \mathrm{Ba}$ technique overlaps with typical ages of deposits from fast-, intermediate- and slow-spreading ridges, and volcanic arcs [de Ronde et al., 2005; Ditchburn et al., 2012], this dating technique should be applicable to barite-hosted seafloor sulfide deposits from a range of tectonic environments.

\section{Conclusions}

[33] Radium-226 dating of hydrothermal barite provides an important chronometer for investigating the temporal evolution of hydrothermal vents. Barite is a common mineral in many hydrothermal settings and is resistant to seafloor weathering processes. The ${ }^{226} \mathrm{Ra} / \mathrm{Ba}$ technique provides an important bridge between shorter- and longer-lived isotope systems for dating seafloor hydrothermal deposits and is applied here for the first time to MOR systems. Using this technique, 61 samples were analyzed from the Endeavour Segment, 12 samples of zero age, and 49 samples with ages that range from 25 to 5850 years old. Current

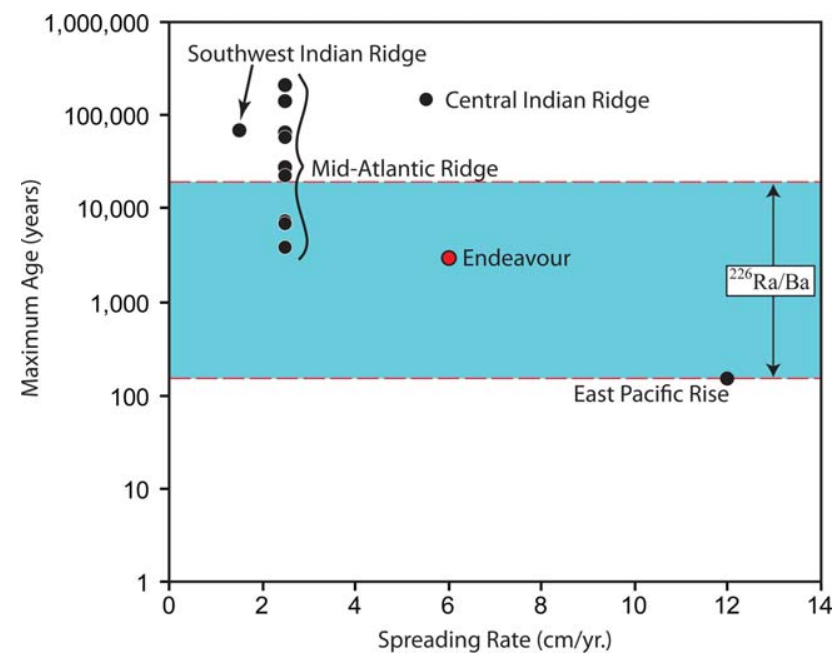

Figure 7. Plot of the maximum sulfide ages recorded from sulfide deposits within the axial valleys of MORs and spreading rate, with the maximum age from Endeavour of $\sim 5850$ years highlighted in red. Older deposits tend to occur on slower spreading ridges. The effective age range for the ${ }^{226} \mathrm{Ra} / \mathrm{Ba}$ technique is highlighted in blue. Data sources are the same as in Figure 6 . 
hydrothermal activity at MEF, High Rise, and Sasquatch fields has been ongoing for the past $\sim 2270$, $\sim 850$, and $\sim 1470$ years, respectively. At MEF and High Rise, the majority of samples have ages between 500 and 1500 years, and the data show no significant hiatuses in venting throughout their histories. This information could provide constraints on the timing and mechanisms of vent field faunal colonization and community evolution.

[34] Hydrothermal venting at the Endeavour Segment is intimately linked to diking events, associated faulting, and magma lenses that extend beneath all known currently active vent sites. The temporal and spatial history of venting appears to have been closely related to the evolution of the axial valley. The link between hydrothermal activity and axial valley evolution can be broken down into three stages: (1) initiation of new normal faulting 5850 years ago, and formation of a shallow, broad axial valley, with subsequent hydrothermal activity throughout the valley floor; (2) at $\sim 1700$ years ago, further faulting resulted in significant hydrothermal deposition being constricted to a new deeper axial valley floor; and (3) at $\sim 1230$ years ago, the spatial extent of hydrothermal activity decreases, and is limited to the sites of currently active vent fields. The age of the oldest sulfide sample and the horizontal offset of the axial valley-bounding normal faults result in a calculated fault-accommodated full-spreading rate for this part of the segment of 7.3 $\mathrm{cm} / \mathrm{yr}$, slightly higher than estimates of $\sim 6 \mathrm{~cm} / \mathrm{yr}$ for the entire Juan de Fuca Ridge.

\section{Acknowledgments}

[35] The authors thank William Chadwick, Cornel de Ronde, and Ed Baker for comments on earlier versions of this manuscript. This work was supported by a NSERC PGS scholarship and SEG Canada Foundation Student Research grant to J. W. Jamieson, NSERC Discovery grant to M. D. Hannington, NSF Ocean Sciences grant OCE-0732661 to J. F. Holden, and NSF grant OCE-1038135 to M. K. Tivey. D. A. Clague and the MBARI cruise were supported by a grant to MBARI from the David and Lucile Packard Foundation. Our thanks to the pilots and crews of DSV Alvin, R/V Atlantis, ROV Doc Ricketts, and R/V Western Flyer for their support. Special thanks to NEPTUNE Canada and ROPOS for taking time out of their dives to collect sulfide samples for this study.

\section{References}

Alt, J. C., P. Lonsdale, R. Haymon, and K. Muehlenbachs (1987), Hydrothermal sulfide and oxide deposits on seamounts near 21-degrees-N, East Pacific Rise, Geol. Soc. Am. Bull., 98(2), 157-168.
Baker, E. T., and C. R. German (2004), On the global distribution of hydrothermal vent fields, in Mid-Ocean Ridges: Hydrothermal Interactions Between the Lithosphere and Oceans vol. 148, edited by C. R. German, J. Lin, and L. M. Parson, pp. 245-266, American Geophysical Union, Washington, D.C.

Bohnenstiehl, D. R., R. P. Dziak, M. Tolstoy, C. G. Fox, and M. Fowler (2004), Temporal and spatial history of the 19992000 Endeavour Segment seismic series, Juan de Fuca Ridge, Geochem. Geophys. Geosyst., 5, Q09003, doi:10.1029/ 2004GC000735.

Butterfield, D. A., R. E. McDuff, M. J. Mottl, M. D. Lilley, J. E. Lupton, and G. J. Massoth (1994), Gradients in the composition of hydrothermal fluids from the Endeavour Segment vent field-Phase-separation and brine loss, J. Geophys. Res., 99, 9561-9583.

Butterfield, D. A., I. R. Jonasson, G. J. Massoth, R. A. Feely, K. K. Roe, R. E. Embley, J. F. Holden, R. E. McDuff, M. D. Lilley, and J. R. Delaney (1997), Seafloor eruptions and evolution of hydrothermal fluid chemistry, Philos. Trans. R. Soc. London A, 355(1723), 369-386.

Carbotte, S. M., R. S. Detrick, A. Harding, J. P. Canales, J. Babcock, G. Kent, E. Van Ark, M. Nedimovic, and J. Diebold (2006), Rift topography linked to magmatism at the intermediate spreading Juan de Fuca Ridge, Geology, 34, 209-212.

Carbotte, S. M., J. P. Canales, M. R. Nedimovic, H. Carton, and J. C. Mutter (2012), Recent seismic studies at the East Pacific Rise $8^{\circ} 20^{\prime}-10^{\circ} 10^{\prime} \mathrm{N}$ and Endeavour Segment insights into mid-ocean ridge hydrothermal and magmatic processes, Oceanography, 25(1), 100-112.

Cherkashov, G., et al. (2010), Seafloor massive sulfides from the Northern Equatorial Mid-Atlantic Ridge: New discoveries and perspectives, Mar. Georesour. Geotechnol., 28(3), 222-239.

Clague, D. A., D. W. Caress, H. Thomas, D. Thompson, M. Calarco, J. Holden, and D. Butterfield (2008), Abundance and distribution of hydrothermal chimneys and mounds on the Endeavour Ridge determined by $1-\mathrm{m}$ resolution AUV multibeam mapping surveys, Eos Trans. AGU, 89(53), Fall Meet. Suppl., Abstract V41B-2079.

Converse, D. R., H. D. Holland, and J. M. Edmond (1984), Flow-rates in the axial hot springs of the East Pacific Rise (21-degrees-N)-Implications for the heat budget and the formation of massive sulfide deposits, Earth Planet. Sci. Lett., 69(1), 159-175.

Davis, E., and H. Elderfield (2004), Hydrogeology of the Oceanic Lithosphere, Cambridge University Press, Cambridge, UK.

Davis, E. E., K. Wang, R. E. Thomson, K. Becker, and J. F. Cassidy (2001), An episode of seafloor spreading and associated plate deformation inferred from crustal fluid pressure transients, J. Geophys. Res., 106, 21953-21963.

de Ronde, C. E. J., et al. (2005), Evolution of a submarine magmatic-hydrothermal system: Brothers volcano, Southern Kermadec Arc, New Zealand, Econ. Geol., 100(6), 10971133.

de Ronde, C. E. J., et al. (2011), Submarine hydrothermal activity and gold-rich mineralization at Brothers Volcano, Kermadec Arc, New Zealand, Miner. Deposita, 46(5-6), 541584.

Delaney, J., R. McDuff, V. Robigou, A. Schultz, M. Smith, J. Wells, V. Atnipp, and J. McClain (1990), Covariation in microseismicity and hydrothermal output in the Endeavour vent field (Abstract), Eos Trans. AGU, 71, 1609.

Delaney, J. R., V. Robigou, R. E. McDuff, and M. K. Tivey (1992), Geology of a vigorous hydrothermal system on the 
Endeavour Segment, Juan de Fuca Ridge, J. Geophys. Res., 97, 19,663-19,682.

Ditchburn, R., I. Graham, B. Barry, and C. de Ronde (2004), Uranium series disequilibrium dating of black smoker chimneys, N. Z. Sci. Rev., 61, 54-56.

Ditchburn, R. G., C. E. J. de Ronde, and B. J. Barry (2012), Radiometric dating of volcanogenic massive sulfides and associated iron oxide crusts with an emphasis on Ra-226/Ba and Ra-228/Ra-226 in volcanic and hydrothermal processes at intraoceanic arcs, Econ. Geol., 107(8), 1635-1648.

Embley, R. W., W. W. Chadwick, I. R. Jonasson, D. A. Butterfield, and E. T. Baker (1995), Initial results of the rapid response to the 1993 Coaxial event-Relationships between hydrothermal and volcanic processes, Geophys. Res. Lett., $22,143-146$.

Glickson, D. A., D. S. Kelley, and J. R. Delaney (2006), The Sasquatch hydrothermal field: Linkages between seismic activity, hydrothermal flow, and geology, Eos Trans. $A G U$, 87(52), Fall Meet. Suppl., Abstract V23B-0614.

Glickson, D. A., D. S. Kelley, and J. R. Delaney (2007), Geology and hydrothermal evolution of the Mothra Hydrothermal Field, Endeavour Segment, Juan de Fuca Ridge, Geochem. Geophys. Geosyst., 8, Q06010, doi:10.1029/ 2007GC001588

Goldstein, S. J., M. T. Murrell, D. R. Janecky, J. R. Delaney, and D. A. Clague (1991), Geochronology and petrogenesis of MORB from the Juan de Fuca and Gorda Ridges by U-238 Th-230 disequilibrium, Earth Planet. Sci. Lett., 107(1), 25-41.

Grasty, R. L., C. W. Smith, J. M. Franklin, and I. R. Jonasson (1988), Radioactive orphans in barite-rich chimneys, Axial Caldera, Juan-de-Fuca Ridge, Can. Mineral., 26, 627-636.

Hannington, M., C. de Ronde, and S. Petersen (2005), Seafloor tectonics and submarine hydrothermal systems, in Economic Geology, 100th Anniversary Volume, edited by J. W. Hedenquist, J. F. H. Thompson, R. J. Goldfarb, and J. P. Richards, pp. 111-141. J. P. Society of Economic Geologists, Littleton, Colorado, USA.

Hannington, M., J. Jamieson, T. Monecke, S. Petersen, and S. Beaulieu (2011), The abundance of seafloor massive sulfide deposits, Geology, 39(12), 1155-1158.

Hooft, E. E. E., et al. (2010), A seismic swarm and regional hydrothermal and hydrologic perturbations: The northern Endeavour Segment, February 2005, Geochem. Geophys. Geosyst., 11, Q12015, doi:10.1029/2010GC003264.

Johnson, H. P., M. Hutnak, R. P. Dziak, C. G. Fox, I. Urcuyo, J. P. Cowen, J. Nabelek, and C. Fisher (2000), Earthquakeinduced changes in a hydrothermal system on the Juan de Fuca mid-ocean ridge, Nature, 407(6801), 174-177.

Johnson, H. P., M. A. Tivey, T. A. Bjorklund, and M. S. Salmi (2010), Hydrothermal circulation within the Endeavour Segment, Juan de Fuca Ridge, Geochem. Geophys. Geosyst., 11, Q05002, doi:10.1029/2009GC002957.

Kadko, D., and D. A. Butterfield (1998), The relationship of hydrothermal fluid composition and crustal residence time to maturity of vent fields on the Juan de Fuca Ridge, Geochim. Cosmochim. Acta, 62(9), 1521-1533.

Kadko, D., R. Koski, M. Tatsumoto, and R. Bouse (1985), An estimate of hydrothermal fluid residence times and vent chimney growth-rates based on $\mathrm{Pb}-210-\mathrm{Pb}$ ratios and mineralogic studies of sulfides dredged from the Juan-de-Fuca Ridge, Earth Planet. Sci. Lett., 76(1-2), 35-44.

Kappel, E. S., and W. B. F. Ryan (1986), Volcanic episodicity and a nonsteady state rift-valley along northeast Pacific spreading centers-Evidence from Sea Marc-I, J. Geophys. Res., 91, 13925-13940.
Karsten, J. L., J. R. Delaney, J. M. Rhodes, and R. A. Liias (1990), Spatial and temporal evolution of magmatic systems beneath the Endeavour Segment, Juan de Fuca Ridge-Tectonic and petrologic constraints, J. Geophys. Res., 95, 19,235-19,256.

Kelley, D. S., J. R. Delaney, and D. R. Yoerger (2001), Geology and venting characteristics of the Mothra hydrothermal field, Endeavour Segment, Juan de Fuca Ridge, Geology, 29(10), 959-962.

Kelley, D. S., J. A. Baross, and J. R. Delaney (2002), Volcanoes, fluids, and life at mid-ocean ridge spreading centers, Annu. Rev. Earth Planet. Sci., 30, 385-491.

Kelley, D. S., et al. (2012), Endeavour Segment of the Juan de Fuca Ridge: One of the most remarkable places on earth, Oceanography, 25(1), 44-61.

Kim, K. H., and G. M. McMurtry (1991), Radial growth-rates and $\mathrm{Pb}-210$ ages of hydrothermal massive sulfides from the Juan de Fuca Ridge, Earth Planet. Sci. Lett., 104(2-4), 299314.

Kreemer, C., W. E. Holt, and A. J. Haines (2003), An integrated global model of present-day plate motions and plate boundary deformation, Geophys. J. Int., 154(1), 8-34.

Kristall, B., D. S. Kelley, M. D. Hannington, and J. R. Delaney (2006), Growth history of a diffusely venting sulfide structure from the Juan de Fuca Ridge: A petrological and geochemical study, Geochem. Geophys. Geosyst., 7, Q07001, doi:10.1029/2005GC001166.

Kristall, B., D. Nielsen, M. D. Hannington, D. S. Kelley, and J. R. Delaney (2011), Chemical microenvironments within sulfide structures from the Mothra Hydrothermal Field: Evidence from high-resolution zoning of trace elements, Chem. Geol., 290(1-2), 12-30.

Kuznetsov, V., F. Maksimov, A. Zheleznov, G. Cherkashov, V. BeL'Tenev, and L. Lazareva (2011), Th-230/U chronology of ore formation within the Semyenov Hydrothermal District $\left(13^{\circ} 31^{\prime} \mathrm{N}\right)$ at the Mid-Atlantic Ridge, Geochronometria, 38(1), 72-76.

Kuznetsov, Y., G. A. Cherkashev, V. E. Bel'tenev, A. Y. Lein, F. E. Maximov, V. V. Shilov, and T. V. Stepanova (2007), The Th-230/U dating of sulfide ores in the ocean: Methodical possibilities, measurement results, and perspectives of application, Dokl. Earth Sci., 417(8), 1202-1205.

Lalou, C., and E. Brichet (1982), Ages and implications of East Pacific Rise sulfide deposits at 21-Degrees-N, Nature, 300(5888), 169-171.

Lalou, C., E. Brichet, and R. Hekinian (1985), Age dating of sulfide deposits from axial and off-axial structures on the East Pacific Rise near 12-degrees-50'N, Earth Planet. Sci. Lett., 75(1), 59-71.

Lalou, C., J. L. Reyss, E. Brichet, P. A. Rona, and G. Thompson (1995), Hydrothermal activity on a 10(5)-year scale at a slow-spreading ridge, TAG hydrothermal field, mid-Atlantic Ridge 26-degrees-N, J. Geophys. Res., 100, 17,855-17,862.

Lalou, C., J. L. Reyss, E. Brichet, S. Krasnov, T. Stepanova, G. Cherkashev, and V. Markov (1996), Initial chronology of a recently discovered hydrothermal field at 14 degrees $45^{\prime} \mathrm{N}$, Mid-Atlantic Ridge, Earth Planet Sci. Lett., 144(3-4), 483490.

Lalou, C., U. Munch, P. Halbach, and J. L. Reyss (1998), Radiochronological investigation of hydrothermal deposits from the MESO zone, Central Indian Ridge, Mar. Geol., $149(1-4), 243-254$.

Langmuir, C., et al. (1997), Hydrothermal vents near a mantle hot spot: The Lucky Strike vent field at 37 degrees N on the Mid-Atlantic Ridge, Earth Planet. Sci. Lett., 148(1-2), 69-91. 
Larson, B. I., M. D. Lilley, and E. J. Olson (2009), Parameters of subsurface brines and hydrothermal processes 12-15 months after the 1999 magmatic event at the Main Endeavor Field as inferred from in situ time series measurements of chloride and temperature, J. Geophys. Res., 114, B01207, doi: 10.1029/2008JB005627.

Lilley, M. D., D. A. Butterfield, J. E. Lupton, and E. J. Olson (2003), Magmatic events can produce rapid changes in hydrothermal vent chemistry, Nature, 422(6934), 878-881.

Lowell, R. P., P. A. Rona, and R. P. Vonherzen (1995), Seafloor hydrothermal systems, J. Geophys. Res., 100, 327-352.

Macdonald, K. C. (1982), Mid-ocean ridges-Fine scale tectonic, volcanic and hydrothermal processes within the plate boundary zone, Annu. Rev. Earth Planet. Sci., 10, 155-190.

Moore, W. S., and D. Stakes (1990), Ages of barite-sulfide chimneys from the Mariana Trough, Earth Planet. Sci. Lett., 100(1-3), 265-274.

Munch, U., C. Lalou, P. Halbach, and H. Fujimoto (2001), Relict hydrothermal events along the super-slow Southwest Indian spreading ridge near 63 degrees $56^{\prime} \mathrm{E}-$ Mineralogy, chemistry and chronology of sulfide samples, Chem. Geol., 177(3-4), 341-349.

Petersen, S., K. Kuhn, T. Kuhn, N. Augustin, R. Hekinian, L. Franz, and C. Borowski (2009), The geological setting of the ultramafic-hosted Logatchev hydrothermal field (14 degrees $45^{\prime} \mathrm{N}$, Mid-Atlantic Ridge) and its influence on massive sulfide formation, Lithos, 112(1-2), 40-56.

Proskurowski, G., M. D. Lilley, and T. A. Brown (2004), Isotopic evidence of magmatism and seawater bicarbonate removal at the endeavour hydrothermal system, Earth Planet. Sci. Lett., 225(1-2), 53-61.

Reyes, A. O., W. S. Moore, and D. S. Stakes (1995), Th-228/ Ra-228 ages of a barite-rich chimney from the Endeavour Segment of the Juan-de-Fuca Ridge, Earth Planet. Sci. Lett., 131(1-2), 99-113.

Riddihough, R. (1984), Recent movements of the Juan-deFuca plate system, J. Geophys. Res., 89, 6980-6994.

Robigou, V., J. R. Delaney, and D. S. Stakes (1993), Large massive sulfide deposits in a newly discovered active hydrothermal system, the Highrise Field, Endeavour Segment, Juan-deFuca Ridge, Geophys. Res. Lett., 20(17), 1887-1890.

Seyfried, W. E., J. S. Seewald, M. E. Berndt, K. Ding, and D. I. Foustoukos (2003), Chemistry of hydrothermal vent fluids from the Main Endeavour Field, northern Juan de Fuca Ridge: Geochemical controls in the aftermath of June 1999 seismic events, J. Geophys. Res., 108(B9), 2429, doi:10.1029/ 2002JB001957.
Shilov, V. V., V. E. Bel'tenev, V. N. Ivanov, G. A. Cherkashev, I. I. Rozhdestvenskaya, I. F. Gablina, I. G. Dobretsova, E. V. Narkevskii, A. N. Gustaitis, and V. Y. Kuznetsov (2012), New hydrothermal ore fields in the Mid-Atlantic Ridge: Zenith-Victoria (20 degrees $08^{\prime} \mathrm{N}$ ) and Petersburg (19 degrees 52' N), Dokl. Earth Sci., 442(1), 63-69.

Solomon, S. C., P. Y. Huang, and L. Meinke (1988), The seismic moment budget of slowly spreading ridges, Nature, 334(6177), 58-60.

Sours-Page, R., K. T. M. Johnson, R. L. Nielsen, and J. L. Karsten (1999), Local and regional variation of MORB parent magmas: Evidence from melt inclusions from the Endeavour Segment of the Juan de Fuca Ridge, Contrib. Mineral. Petrol., 134(4), 342-363.

Stakes, D., and W. S. Moore (1991), Evolution of hydrothermal activity on the Juan-de-Fuca Ridge-Observations, mineral ages, and $\mathrm{Ra}$ isotope ratios, J. Geophys. Res., 96, $21,739-21,752$.

Tivey, M. K., and J. R. Delaney (1986), Growth of large sulfide structures on the Endeavour Segment of the Juande-Fuca Ridge, Earth Planet. Sci. Lett., 77(3-4), 303317.

Tivey, M. K., D. S. Stakes, T. L. Cook, M. D. Hannington, and S. Petersen (1999), A model for growth of steep-sided vent structures on the Endeavour Segment of the Juan de Fuca Ridge: Results of a petrologic and geochemical study, $J$. Geophys. Res., 104, 22,859-22,883.

Van Ark, E. M., R. S. Detrick, J. P. Canales, S. M. Carbotte, A. J. Harding, G. M. Kent, M. R. Nedimovic, W. S. D. Wilcock, J. B. Diebold, and J. M. Babcock (2007), Seismic structure of the Endeavour Segment, Juan de Fuca Ridge: Correlations with seismicity and hydrothermal activity, $J$. Geophys. Res., 112, B02401, doi:10.1029/2005JB004210.

Volpe, A. M., and S. J. Goldstein (1993), Ra-226 Th-230 disequilibrium in axial and off-axis mid-ocean ridge basalts, Geochim. Cosmochim. Acta, 57(6), 1233-1241.

Von Damm, K. L. (1990), Seafloor hydrothermal activityBlack smoker chemistry and chimneys, Annu. Rev. Earth Planet. Sci., 18, 173-204.

Wang, Y. J., X. Q. Han, X. L. Jin, Z. Y. Qiu, Z. B. Ma, and H. L. Yang (2012), Hydrothermal activity events at Kairei field, Central Indian Ridge 25 degrees S, Resour. Geol., 62(2), 208-214.

Wilcock, W. S. D., E. E. E. Hooft, D. R. Toomey, P. R. McGill, A. H. Barclay, D. S. Stakes, and T. M. Ramirez (2009), The role of magma injection in localizing blacksmoker activity, Nature Geosci., 2(7), 509-513. 